Biogeosciences Discuss., https://doi.org/10.5194/bg-2017-430

Manuscript under review for journal Biogeosciences

Discussion started: 16 November 2017

(c) Author(s) 2017. CC BY 4.0 License.

2

4

5

6
Running head: Biological soil crust restoration

Authors and addresses:

Steven D. Warren (corresponding author: swarren02@fs.fed.us)

US Forest Service, Rocky Mountain Research Station

735 North 500 East

Provo, UT 84606-1856

USA

Larry L. St. Clair

Department of Biology \& Monte L. Bean Life Science Museum

Brigham Young University

Provo, UT 84602

USA

Steven D. Leavitt

Department of Biology \& Monte L. Bean Life Science Museum Brigham Young University

Provo, UT 84602

USA

Author contributions: Conceived and originally written by Warren. Edited and additional material by St.Clair and Leavitt. 
Biogeosciences Discuss., https://doi.org/10.5194/bg-2017-430

Manuscript under review for journal Biogeosciences

Discussion started: 16 November 2017

(c) Author(s) 2017. CC BY 4.0 License.

27 Abstract: Biological soil crusts (BSCs) commonly occupy the surface of many arid and semiarid soils, and disturbed soils in more mesic environments. BSCs perform many essential ecological services. Substantial resources have been invested trying to restore BSCs that have been damaged by anthropogenic disturbances, largely to no avail. The nexus of science related to crust restoration and to aerobiology strongly suggests that crusts can become reestablished via naturally occurring processes. Propagules of BSC organisms are found naturally in the atmosphere, and are transported long distances. Whether restoration occurs naturally in this way, or by costly attempts to produce and disseminate artificial inoculants, success is ultimately moderated and governed by the timing and frequency of adequate precipitation relative to the arrival of viable propagules on suitable substrate at an appropriate time of the year. For greatest ecological benefit, efforts should focus primarily on minimizing the scope and scale of anthropogenic disturbance of BSCs in arid ecosystems.

Key words: cyanobacteria, algae, lichens, bryophytes, airborne, reclamation, arid lands 
Biological soil crusts (BSCs) develop when various combinations of diminutive cyanobacteria, algae, nonlichenized fungi, lichens, and/or bryophytes occupy the surface and upper few millimeters of the soil. Historically, they have been referred to as cryptobiotic, cryptogamic, microbiotic, microfloral, microphytic, and organogenic crusts. They can be present in a wide range of ecological, successional, and climatic conditions when and where disturbance and/or aridity have resulted in opportunities for colonization. However, they are most prevalent in arid and semiarid ecosystems where vascular plant cover and diversity are characteristically low, leaving large areas available for colonization by some combination of the organismal groups mentioned above. The diversity and distribution of components of BSCs in extreme environments is striking. For example, at least 18 species of cyanobacteria have been documented in the soils of Death Valley National Monument in the Mojave Desert, USA, where surface temperatures can reach $88^{\circ} \mathrm{C}$ (Durrell 1962), and, at the opposite end of the temperature spectrum, BSC communities are common in interior Antarctica, where soil temperature seldom exceeds $0^{\circ} \mathrm{C}$ (Green \& Broady 2001). BSCs are also present in the hyperarid Atacama Desert of northern Chile (Patzelt et al. 2014), where average annual precipitation, depending on latitude, elevation, and distance from the Pacific coast, can be less than $1 \mathrm{~mm}$.

The ecological roles of BSCs are many and varied, and include the collection, accumulation, and cycling of essential airborne and soil nutrients, redistribution of precipitated water, and soil stabilization (Warren 1995; Belnap \& Lange 2001; Weber et al. 2016). BSCs, and their ecological functions, can be disturbed by a variety of factors, including, but not limited to, livestock trampling (Warren \& Eldridge 2001), off-road vehicular traffic (Wilshire 1983; Webb et al. 1988), military training (Warren 2014), and fire (Johansen 2001). In spite of the overall importance of BSCs and the well-documented effects of disturbance on these communities, restoring degraded habitats has received proportionately little attention (Bowker 2007). Reflection on the broader scope of BSC restoration can improve our perspective of how to effectively manage important dryland regions, in addition to directing future research.

\section{Artificial Restoration}

It may seem intuitive to attempt to restore BSCs by inoculating disturbed sites with crust organisms, but such applications have been relatively rare. St. Clair et al. (1986) inoculated small plots with a soil slurry made by stripping BSCs from intact areas, mixing them with water, and applying them on a site damaged by wildfire. Belnap (1993) stripped crusts from an intact area, and used them as a dry inoculant on small plots where the original crust had been removed. The inoculation of soil in petri dishes with dry and slurried inocula, plus additions of water up to 5 times per week and sewage sludge, produced a modicum of establishment (Maestre et al. 2006). Bu et al. (2014) inoculated soil in a greenhouse study with BSCs that had been stripped from intact areas in the field in an attempt to accelerate crust restoration. They 
Biogeosciences Discuss., https://doi.org/10.5194/bg-2017-430

Manuscript under review for journal Biogeosciences

Discussion started: 16 November 2017

(c) Author(s) 2017. CC BY 4.0 License.

found that frequent watering of the crusts in that setting enhanced growth, but field trials were not conducted. In the Mojave Desert, USA, a somewhat similar approach was attempted using crusts composed of cyanobacteria, lichens and bryophytes that had been salvaged from a road construction site and subsequently stored for two years (Chiquoine et al. 2016). Cole et al. (2010) transplanted soil cores with intact bryophyte crusts in the Mojave Desert, USA. The cover and density of the bryophytes declined after transplantation, but at rates similar to the parent population, suggesting that annual declines are natural even in intact populations. In most of the aforementioned cases, inoculation hastened recovery of BSC organisms, particularly in controlled laboratory settings, with some recovery also in field trials. However, while the results were promising, the destruction of BSCs in one area to provide inoculants for another area is counterproductive in the context of large-scale arid land reclamation. Use of salvaged crusts from construction sites is promising for limited areas (Chiquione et al. 2016). It is unlikely that providing sufficient supplemental water for successful large-scale reclamation in arid environments will be feasible.

Related research has investigated the potential for ex situ laboratory-grown BSC amendments for use in inoculating disturbed areas (Zhao et al. 2016). For example, Buttars et al. (1998) incorporated laboratory-grown cyanobacteria into alginate pellets. The cyanobacteria were unable to escape intact pellets; however, crushing the pellets, and applying them to moistened soil in the laboratory resulted in significant increases in cyanobacterial biomass and frequency, and nitrogen fixation. Incorporation of cyanobacteria into starch pellets was not successful due to poor survival during the pelletization process (Howard \& Warren 1998). Kubečková et al. (2003) grew cyanobacteria and immobilized it on hemp cloth. Laboratory trials indicated improved growth compared to alginate pellets, but in four of five field trials, there was no significant crust recovery. The general lack of success was attributed, at least in part, to the placement of the inoculants on the soil surface where some species can be negatively affected by incident UV radiation (Garcia-Pichel \& Castenholz 1991). If sensitive species occur at a depth off 1-2 mm, UV radiation is attenuated (Dor and Danin 2001). When cyanobacterial inoculants have been applied to the soil surface, rather than incorporated into the surface layer of the soil, mortality has been high. Bowker and Antoninka (2016) sucessfully grew mixed cultures of the lichen Collema and the moss Syntrichia in the laboratory, but field applications of the BSC organism mix have not been attempted. Moss protonema transplanted into the sands of the Gurbantunggut Desert of China from laboratory-grown mosses has seen some success when supplemented with liquid growth media (Xu et al. 2008). Mosses have been successfully propagated in the laboratory with frequent watering and fertilization (Antoninka et al. 2016) although field trials have not been conducted. The addition of laboratory grown cyanobacteria to polyvinyl alcohol and a liquid soil tackifier appeared to accelerate the formation of a BSC in a laboratory setting (Park et al. 2017). 
Biogeosciences Discuss., https://doi.org/10.5194/bg-2017-430

Manuscript under review for journal Biogeosciences

Discussion started: 16 November 2017

(c) Author(s) 2017. CC BY 4.0 License.

121

Although some degree of success has been noted, large-scale field trials have not been attempted, and successful ex situ growth is not ubiquitous across BSC components. Given the general lack of success of artificial techniques to restore the BSC component, the levels of water required, and the per-acre costs, it is reasonable to question whether these approaches merit further consideration in arid areas except in critical situations where cost is not a constraint.

\section{Passive Restoration}

The fact that BSCs are found in almost all environments, ranging from mesic to hyperarid, and from temperate to extremely hot or cold, justifies the question as to how crust organisms became so spatially and climatically dispersed in the first place, and if the same processes are still operating. In general, as the post-disturbance succession takes place, the initial colonizers tend to be large filamentous cyanobacteria (Belnap \& Eldridge 2001). As the surface becomes stabilized, the next to appear are smaller cyanobacteria and green algae. They are often followed by small lichens. Where climatic conditions permit, larger lichens and mosses appear in later successional communities. The distribution and successful establishment of these organisms is governed both by historical and contemporary factors (Leavitt and Lumbsch 2016).

Estimates of the time required for natural recovery of BSCs following disturbance have varied widely depending on the nature, periodicity, extent, and spatial and temporal distribution of the disturbance, and soil and climatic conditions. Dohani et al. (2011) reported significant recovery to a level beyond the pre-disturbance condition within one year (one moist season) on the Succulent Karoo semi-desert of South Africa where the upper $10 \mathrm{~mm}$ of the soil surface was removed. Five years following one-time human trampling, Cole (1990) noted a nearly complete recovery of visible BSC cover, although the complex pinnacled surface microtopography attributable to many crusts had not recovered to pre-disturbance levels. Read et al. (2011) labeled as 'surprisingly fast' the recovery of biological soil crusts following livestock removal from an area that had been previously heavily disturbed by livestock grazing in Australia. Anderson et al. (1982) estimated that 14-18 years were adequate for recovery of a BSC following exclusion of livestock grazing in the cool Great Basin Desert, USA. Johansen and St. Clair (1986) recorded significant, albeit incomplete, recovery of BSC diversity and abundance, in the Great Basin, USA, 7 years following the cessation of grazing on an areas with a long history of heavy grazing. In contrast, there was little evidence of recovery during the first 10 years following cessation of grazing at another Great Basin Desert location (Jeffries \& Klopatek 1987). Recovery lagged 20 years following burning of a shrub community in the transition zone between the Great Basin and Mojave Deserts in southwestern Utah, USA (Callison et al. 1985). Belnap (1993) estimated that full recovery of BSCs in the Great Basin 
Biogeosciences Discuss., https://doi.org/10.5194/bg-2017-430

Manuscript under review for journal Biogeosciences

Discussion started: 16 November 2017

(c) Author(s) 2017. CC BY 4.0 License.

Desert, USA, including visual as well as functional characteristics, could require as long as 30-40 years for the cyanobacterial component, 45-85 years for lichens, and 250 years for mosses. Fifty-six years following abandonment of a military training camp in the Sonoran Desert, USA, a cyanobacterial crust had not recovered to levels typical of adjacent undisturbed areas (Kade \& Warren 2002). In the Mojave Desert, USA, according to measurements taken inside and outside of tank tracks created during training for World War II, and assuming a worst-case linear trajectory scenario, full recovery of the cyanobacterial component of the BSC was estimated to require up to 85-120 years (Belnap \& Warren 2002).

Similar temporal patterns of BSC recovery following disturbance have been recorded in other regions. In Australia, near complete recovery was documented after 20 years on pastures that had been grazed moderately, while heavily grazed pastures recovered at a much slower rate (Read et al. 2011). Eldridge \& Ferris (199) suggested that at least 60 years would be required for full recovery of lichens at a nuclear test site in the Great Victoria Desert of Australia. In an extreme case, Lalley \& Viles (2008) estimated that full recovery of lichens in badly disturbed truck ruts in the hyper-arid Namib Desert could take up to 530 years without climatic or anthropogenic intervention. It is important to note, however, that the rate of recovery is likely dependent on the arrival of viable propagules onto suitable substrates at times consistent with adequate moisture. Such conditions may be episodic and infrequent, particularly in the drier and hotter arid zones. We have personally witnessed significant recovery of crust organisms within 2 years following wildfire in the Great Basin Desert, USA, when suitable conditions prevailed.

Regardless of the timeframe required, recovery is dependent on several factors: (1) arrival of suitable propagules, (2) existence of an appropriate substrate on which to establish, including soil texture and chemistry, and (3) timing of the arrival of propagules in relation to cyclical soil moisture conditions necessary for establishment. The failure of any one of the necessary components may substantially delay successful reestablishment.

\section{Aerobiology}

As early as 1846, Charles Darwin collected dust from surfaces of HMS Beagle during one of his voyages of exploration, and discovered 17 different organisms (Darwin 1846). Meier \& Lindbergh (1935) collected airborne organisms from a fixed-wing aircraft on a flight over the Arctic from Maine to Denmark. Shortly thereafter, but not necessarily correlated with that event, the field of aerobiology was established, originally emphasizing studies of airborne fungi, bacteria, and viruses associated with respiratory illnesses from indoor environments (Benninghoff 1991). Subsequently, the field began to evaluate other potential airborne allergens including protozoans, minute arthropods, algae, and cyanobacteria in the atmosphere, and began to evaluate the seasonality and other factors affecting their presence. 
Biogeosciences Discuss., https://doi.org/10.5194/bg-2017-430

Manuscript under review for journal Biogeosciences

Discussion started: 16 November 2017

(c) Author(s) 2017. CC BY 4.0 License.

As a consequence, the presence of large numbers of cyanobacteria and algae have been documented as being present in indoor and outdoor airborne environments ranging from low to high altitudes above the Earth (Schlichting 1969; Sharma et al. 2007; Genitsaris et al. 2011; Després et al. 2012; Tesson et al. 2016). Recent studies have revealed the presence of hundreds of BSC taxa and thousands of individuals in dust samples collected from the external surfaces of homes around the United States (Barberán et al. 2015). It has been recently suggested that some organisms may go through multiple generations while in the atmosphere, such that the atmosphere becomes a truly aerial habitat (Womack et al. 2010). Unsurprisingly, many of the species documented in the atmosphere are also common in BSC communities.

Airborne BSC organisms may be deposited almost anywhere. For example, algae and cyanobacteria have been reported to occur on high latitude and high elevation glaciers from the Arctic to the Antarctic (Marshall \& Chalmers 1997; Harding et al. 2011; Kvíderová 2012; Takeuchi 2013; Vonnahme 2016). They have been collected from building facades (Samad \& Adhikary 2008; Sethi et al. 2012), stone monuments (Tomaselli et al. 2000; Macedo et al. 2009), exposed rocks (Danin 1999) and plant surfaces (Sethi et al. 2012; McGorum et al. 2015). In addition to algae and cyanobacteria, other BSC components can also be dispersed by wind. These include non-lichenized fungi (Miller \& McDaniel 2004; Golan and Pringle 2017), asexual reproductive lichen fragments, soredia, and/or lichen-forming fungal spores (Marshall 1996; Heinken 1999; Tormo et al. 2001; Bailey 1966; Leavitt and Lumbsch 2016), as well as spores, gametophyte fragments, and specialized asexual diaspores of bryophytes (Stark 2003; LaakaLindberg et al. 2003; Pohjamo et al. 2006; Lönnell et al. 2012). This pattern of airborne dispersal of BSC propagules has resulted in many species occurring in both the northern and southern polar regions, Iceland, and extreme southern Chile (Piñeiro et al. 2012).

\section{Atmospheric mixing and dispersion}

A logical question may arise as to how BSC organisms are able to achieve airborne status. Many people living in arid and hyperarid regions of the world have, at one time or another, heard stories of, or personally witnessed, dust storms that develop when strong nonconvective horizontal winds blowing over unconsolidated soil surfaces pick up large quantities of soil. Although not at all limited to the Dust Bowl era, such conditions prevailed in the 1930's in the North America (McLeman et al. 2014). Similarly, strong dust storms have been recorded in Alaska (Nickling 1978), China (Wang et al. 2004), Australia (Ekström et al. 2004), Africa (Prospero \& Mayor-Bacero 2013), and the Middle East (Almuhanna 2015). On a smaller, but much more common scale, dust may be lifted into the atmosphere by strong vertical vortices or 'dust devils' (Metzger et al. 2011; Horton et al. 2016).

Once airborne, dust particles and the BSC organisms that often accompany them, are subject to a variety of forces that carry them between hemispheres, continents, and climatic 
Biogeosciences Discuss., https://doi.org/10.5194/bg-2017-430

Manuscript under review for journal Biogeosciences

Discussion started: 16 November 2017

(c) Author(s) 2017. CC BY 4.0 License.

zones (Griffin et al. 2002; Prospero \& Lamb 2003; Kellogg \& Griffin 2006; Uno et al. 2009). Near the Earth's surface, airborne particles are carried predominantly by trade winds, which were given their name because of the effect they had on global oceanic trade prior to the advent of powered locomotion. Trade winds exist in six major belts which circle the globe. Between the equator and 30 north or south latitude, the trade winds generally blow from east to west; between 30 and 60 latitude, the winds shift to from west to east; between 60 north or south latitude and the respective poles, easterly winds again prevail. The major jet streams exist at about 9-15 km above the Earth's surface and blow from west to east (Lewis 2003). They meander north or south, and may cross between the northern and southern hemispheres (Rangarajan \& Eapen 2012). Other than the trade winds and jet streams, a primary force mixing the atmosphere within the southern and northern hemispheres are the global Hadley, Ferrel and polar cells (Kjellsson \& Döös 2012; Huang and McElroy 2014) which correspond latitudinally with the trade wind belts. Hadley cells begin where warm air rises near the equator, generally resulting in heavy rainfall. After reaching the upper atmosphere the Hadley cells carry the flow of air poleward. At approximately $30^{\circ}$ north and south latitude, the Hadley cells diverge earthward, converging with the downward flow of the Ferrel cells bringing air masses from higher latitudes. The result in both hemispheres is a very large body of descending dry air and high pressure. As descending air masses typically offer little precipitation, the zones of convergence correspond with some of the world's most recognized arid zones. The dry air moves poleward after reaching the Earth's surface. As the Ferrel cells pass over the Earth's surface, they collect moisture until they reach approximately $60^{\circ}$ north and south latitude where the air masses ascend after converging with the polar cells. In order to continue the ascent, the air masses lose moisture, and precipitation increases. The polar cells descend earthward near the poles, a region also widely known for aridity.

Given the forces mixing the atmosphere, and the likelihood for BSC propagules to be present in it, there can be little doubt that organisms originating from almost any given location have the potential to be deposited anywhere on Earth (Jungblut et al. 2010; Barberán et al. 2014; Herbold et al. 2014). Carson and Brown (1976) found little correlation between the diversity of airborne algae, and soil algae at corresponding altitudes on the Island of Hawaii, suggesting atmospheric mixing of airborne organisms. Evidence of mixing can also be seen on a global scale by the similarity of BSC species in the Arctic and Antarctic (Jungblut et al. 2012; Galloway \& Aptroot 1995). Dust deposited in Antarctica originates in Patagonia, Australia, and the Northern Hemisphere (Li et al. 2008). Dust originating during dust storms in China and the Middle East has been documented as arriving in Japan within just a few days (Lee et al. 2006).

272 Dust from the Middle East has been recorded in the Caribbean (Doherty et al. 2008) and the

273 southeastern USA (Prospero 1999). Many BSC propagules carried with dust can survive long

274 periods of desiccation (Holzinger \& Karsten 2013; Rajeev et al. 2013), thus becoming 
Biogeosciences Discuss., https://doi.org/10.5194/bg-2017-430

Manuscript under review for journal Biogeosciences

Discussion started: 16 November 2017

(c) Author(s) 2017. CC BY 4.0 License.

immigrants to BSC communities globally (Rosselli et al. 2015; Rahav et al. 2016). For example, lichen species of South African origin are now present in Australia and South America (Amo de Paz et al. 2012). Similarity of BSC communities is better predicted by the so-called 'dust highways' than by the proximity of source species (Muñoz et al. 2004). Dust and microbial deposition are both seasonal (Sharma et al. 2006; Sahu \& Tangutur 2015) and cyclical over time (Rousseau et al. 2007).

The apparent airborne and global distribution of BSC propagules should not be construed to imply that BSC species composition will be the same worldwide, nor that natural recovery of BSC's will be necessarily rapid. The distribution of BSC propagules is shaped by the dynamic interplay of a range of factors operating across multiple temporal scales. That many propagules are distributed globally is apparently true. However, whether they will develop and thrive is still dependent on being deposited on appropriate substrate, with appropriate being defined as suitable in terms of chemistry, fertility, particle and pore size analysis, moisture content and seasonality, and temperature. For example, it is hardly realistic to expect most BSC species adapted to the frigid conditions of polar regions to survive and persist in hot deserts, and vice versa.

\section{The nexus of aerobiology and land reclamation}

The use of corn stalk fences and wheat straw checkboard sand barriers to stabilize moving sands of sand dunes have been successfully used for years to stabilize moving sand dunes in China (Qiu et al. 2004; Zhang et al. 2004; Li et al. 2006). These barriers create turbulence in the flow of wind across the dune surfaces, and cause the deposition of sand particles and associated BSC organisms. Researchers have discovered that biological soil crust organisms precipitated in this fashion can successfully colonize stabilized dunes (Li et al. 2003; Guo et al. 2008; Zhang 2014).

One must bear in mind that while airborne BSC propagules may provide an answer to the restoration of BSCs in many situations, their presence and composition depends on climatic conditions in locations very far away. As discussed, BSC propagules may originate from distant continents. BSC organisms from a specific soil type, chemistry, and alkalinity may not always be suitable for other situations. The arrival of appropriate propagules is likely episodic, seasonal, and less common than desired. There can be little doubt that airborne propagules are found in the atmosphere circling the globe. That they will be deposited in sufficient quantities, and in the right species composition, and at the right season for any specific area remains unknown.

\section{Conclusions}


Over the years, many hundreds of thousands of dollars have been expended on various approaches of crust restoration, often culminating in the production and application of large quantities of inoculants. Most approaches have failed to one degree or another. Those that did not fail, have been so dependent on large quantities of water for production and application, that they are not practical for broad-scale arid and semiarid environments. Several approaches to restoration depended on the destruction of one area to restore another. A review of the field of aerobiology seems to indicate that we may have been 'barking up the wrong tree'. Many propagules of many, if not most BSC organisms are already present and circulating the globe in the atmosphere. Perhaps, now we need to shift to a more natural approach of crust restoration. Whether we artificially produce and apply inoculants, or rely on natural, passive dispersal, the overall success depends on coordination of inoculation with appropriate environmental conditions. At any given location, regardless of the mode of inoculation, success depends on receiving adequate moisture at the right time of year, appropriate substrate, other environmental factors, and some measure of better controlling anthropogenic disturbance to BSC communities. We anticipate that incorporating principles of aerobiology and passive dispersal into the BSC restoration paradigm will facilitate more effective and less costly management of BSCs.

\section{Literature Cited}

Almuhanna, E. A.: Dustfall associated with dust storms in the Al-Ahsa Oasis of Saudi Arabia,

Amo de Paz, G., Cubas, P., Crespo, A., Elix, J. A., and Lumbsch, H. T.: Transoceanic dispersal and subsequent diversification on separate continents shaped diversity of the Xanthoparmelia pulla group (Ascomycota), PLOS ONE, 7, e39683, 2012

Anderson, D. C., Harper, K. T., and Rushforth, S. R.: Recovery of cryptogamic soil crusts from grazing on Utah winter ranges, J. Range Manage., 35, 355-359, 1982

Antoninka, A., Bowker, M. A., Reed, S. C., and Doherty, K.: Production of greenhouse-grown biocrust mosses and associated cyanobacteria to rehabilitate dryland soil function, Restor. Ecol., 24, 324-335, 2016

Bailey, R. H.: Studies on the dispersal of lichen soredia. J. Linnean Soc. London, Bot., 59, 479490, 1966

Barberán, A., Henley, J., Fierer, N., and Casamayor, E.O.: Structure, inter-annual recurrence, and global-scale connectivity of airborne microbial communities, Science Total Environ., 487, 187195, 2014 
Biogeosciences Discuss., https://doi.org/10.5194/bg-2017-430

Manuscript under review for journal Biogeosciences

Discussion started: 16 November 2017

(c) Author(s) 2017. CC BY 4.0 License.

Barberán A, Ladau J, Leff JW, Pollard KS, Menninger HL, Dunn RR, and Fierer N.: Continental-

scale distributions of dust-associated bacteria and fungi. Proc. Nat. Acad. Sci., 112, 5756-5761,

2015

Belnap, J.: Recovery rates of cryptobiotic crusts: inoculant use and assessment methods, Great

Belnap, J., and Eldridge, D.: Disturbance and recovery of biological soil crusts. In: Belnap J., and Lange, O. L. (eds), Biological soil crusts: structure, function and management, Springer Verlag,

Belnap, J., and Lange, O. L., (eds).: Biological soil crusts: structure, function and management,

Belnap, J., and Warren, S. D.: Patton's tracks in the Mojave Desert, USA: an ecological legacy,

Benninghoff, W. J.: Aerobiology and its significance in biogeography and ecology, Grana, 30, 9-

Bowker, M. A.: Biological soil crust rehabilitation in theory and practice: An underexploited opportunity. Restor. Ecol., 15, 13-23, 2007

Bowker, M. A., Antoninka, A. J.: Rapid ex situ culture of $\mathrm{N}$-fixing soil lichens and biocrusts is enhanced by complementarity. Plant Soil, doi: 10.1007/s11104-016-2929-7, 2016

Bu, C., Wu, S., Yang, Y., and Zheng, M.: Identification of factors influencing the restoration of cyanobacteria-dominated biological soil crusts, PLOS ONE, 9, e90049, 2014

Buttars, S. M., St. Clair, L. L., Johansen, J. R., Sray, J. C., Payne, M. C., Webb, B. L., Terry, R. E.,

Callison, J., Brotherson, J. D., and Bowns, J. E.: The effects of fire on the blackbrush [Coleogyne ramosissima] community of southwestern Utah, J. Range Manage., 38, 535-538, 1985 
Biogeosciences Discuss., https://doi.org/10.5194/bg-2017-430

Manuscript under review for journal Biogeosciences

Discussion started: 16 November 2017

(c) Author(s) 2017. CC BY 4.0 License.

392

393

394

395

396

397

398

399

400

401

402

403

404

405

406

407

408

409

410

411

412

413

414

415

416

417

418

419

420

421

422

423

424

425

426

427

428

429

430
Chiquoine, L. P., Arbella, S. R., and Bowker, M. A.: Rapidly restoring biological soil crusts and ecosystem functions in a severely disturbed desert ecosystem. Ecol. Appl., 26, 1260-1272, 2016

Cole, C., Stark, L. R., Bonine, M. L., and McLetchie, D. N.: Transplant survivorship of bryophyte soil crusts in the Mojave Desert, Restor. Ecol., 18, 198-205, 2010

Cole, D. N.: Trampling disturbance and recovery of cryptogamic soil crusts in Grand Canyon National Park, Great Basin Nat., 50, 321-325, 1990

Danin, A.: Desert rocks as plant refugia in the Near East. Bot. Rev., 65(2), 93-170, 1999

Darwin, C.: An account of the fine dust which often falls on vessels in the Atlantic Ocean. Q. J. Geol. Soc. London, 2, 26-30, 1846

Després, V. R., Huffman, J. A., Burrows, S. M., Hoose, C., Safatov, A. S., Buryak, G., FröhlichNowoisky, J., Elbert, W., Andreae, M. O., Pöschl, U, and Jaenicke, R.: Primary biological aerosol particles in the atmosphere: a review, Tellus, 64, 11598, 2012

Doherty, O. M., Riemer, N., and Hameed, S.: Saharan mineral dust transport into the Caribbean: Observed atmospheric controls and trends. J. Geophys. Res., 113, D07211, 2008

Dojani, S., Büdel, S., Deutschewitz, K., and Weber, B.: Rapid succession of biological soil crusts after experimental disturbance in the Succulent Karoo, South Africa. Appl. Soil Ecol., 48, 263269, 2011

Dor, I., and Danin, D.: Life strategies of Microcoleus vaginatus: A crust forming cyanophyte on desert soils, Nova Hedwigia, 123, 317-339, 2001

Durrell, L. W.: Algae of Death Valley, Trans. Am. Microscop. Soc., 81, 267-273, 1962

Ekström, M., McTainsh, G. H., and Chappell, A.: Australian dust storms: temporal trends and relationships with synoptic pressure distributions (1960-00), Int. J. Climatol., 24, 1581-1599, 2004

Eldridge, D. J., and Ferris, J. M.: Recovery of populations of the soil lichen Psora crenata after disturbance in arid South Australia, Rangeland J., 21, 194-198, 1999

Galloway, D. J., and Aptroot, A.: Bipolar lichens: a review. Cryptogamic Bot., 5, 184-191, 1995 
Biogeosciences Discuss., https://doi.org/10.5194/bg-2017-430

Manuscript under review for journal Biogeosciences

Discussion started: 16 November 2017

(c) Author(s) 2017. CC BY 4.0 License.

431

432

433

434

435

436

437

438

439

440

441

442

443

444

445

446

447

448

449

450

451

452

453

454

455

456

457

458

459

460

461

462

463

464

465

466

467

468

Garcia-Pichel, F., and Castenholz, R. W.: Characterization and biological implications of scytonemin, a cyanobacterial sheath pigment, J. Phycol., 27, 395-409, 1991

Genitsaris, S., Kormas, K. A., and Moustaka-Gouni, M.: Airborne algae and cyanobacteria: occurrence and related health effects, Front. Biosci., 3, 772-787, 2011

Golan, J. J., and Pringle, A.: Long-distance dispersal of fungi. Microbiol. Spectrum, Jul;5(4), 21650497, doi: 10.1128/microbiolspec.FUNK-0047-2016, 2017

Green, T. G., and Broady, P. A..: Biological soil crusts of Antarctica. in Belnap, J., and Lange, O. L. (eds), Biological soil crusts: structure, function, and management, Springer-Verlag, Berlin, Germany, 133-139, 2001

Griffin, D. W., Kellogg, C. A., Garrison, V. H., and Shinn, E. A.: The global transport of dust: An intercontinental river of dust, microorganisms and toxic chemicals flows through the Earth's atmosphere. Am. Sci., 90, 228-235, 2002

Guo, Y., Zhao, H., Zuo, X., Drake, S., and Zhao, X.: Biological soil crust development and its topsoil properties in the process of dune stabilization, Inner Mongolia, China, Environ. Geol., 54, 653-662, 2008

Harding, T., Jungblut, A. D., Lovejoy, C., and Vincent, W. F.: Microbes in high arctic snow and implications for the cold biosphere. Appl. Environ. Microbiol., 77, 3234-3243, 2011

Heinken, T.: Dispersal patterns of terricolous lichens by thallus fragments. Lichenologist, 31, 603-612, 1999

Herbold, C. W., Lee, C. K., McDonald, I. R., and Cary, S. C.: Evidence of global-scale aeolian dispersal and endemism in isolated geothermal microbial communities of Antarctica. Nat. Commun., 5, 3875, 2014

Holzinger, A., and Karsten, U.: Desiccation stress and tolerance in green algae: consequences for ultrastructure, physiological, and molecular mechanisms. Front. Plant Sci., 4, article 327, 2013

Horton, W., Miura, H., Onishchenko, O., Couede, L., Arnas, C., Escarguel, A., Benkadda, S., and Fedun, V.: , Dust devil dynamics, J. Geophys. Res.: Atmos, 121, 2016 
Biogeosciences Discuss., https://doi.org/10.5194/bg-2017-430

Manuscript under review for journal Biogeosciences

Discussion started: 16 November 2017

(c) Author(s) 2017. CC BY 4.0 License.

Howard, G.L., and Warren, S.D.: The incorporation of cyanobacteria into starch pellets and determination of escapability rates for use in land rehabilitation. US Army Construc. Engin. Res. Lab. Spec. Rep., 98/56, 1998

Huang, J., and McElroy, M. B.: Contributions of the Hadley and Ferrel circulation to the energetics of the atmosphere over the past 32 years, J. Climate, 17, 2656-2666, 2014

Jeffries, D. L., and Klopatek, J. M.: Effects of grazing on the vegetation of the blackbrush association, J. Range Manage., 40, 390-392, 1987

Johansen, J. R.: Impacts of fire on biological soil crusts, in: Belnap, J., and Lange, O. L. (eds), Biological soil crusts: structure, function, and management, Springer-Verlag, Berlin, Germany, 386-397, 2001

Johansen, J. R., and St. Clair, L. L.: Cryptogamic soil crusts: recovery from grazing near Camp Floyd State Park, Utah, USA, Great Basin Nat., 46, 632-640, 1986

Jungblut, A. D., Lovejoy, C., and Vincent, W. F.: Global distribution of cyanobacterial ecotypes in the cold biosphere, ISME J., 4, 191-202, 2010

Jungblut, A. D., Vincent, W. F., and Lovejoy C.: Eukaryotes in Arctic and Antarctic cyanobacterial mats, FEMS Microb. Ecol., 82, 416-428, 2012

Kade, A., and Warren, S. D.: Soil and plant recovery after historic military disturbances in the Sonoran Desert, USA, Arid Land Res. Manage., 16, 231-243, 2002

Kellogg, C. A., and Griffin, D. W.: Aerobiology and the global transport of desert dust. Trends Ecol. Evol., 21, 638-644, 2006

Kjellsson, J., and Döös, K.: Lagrangian decomposition of the Hadley and Ferrel cells. Geophys. Res. Lett., 39, L15807, 2012

Kubečková, K., Johansen, J. R., and Warren, S. D., and Sparks, R.: Development of immobilized cyanobacterial amendments for reclamation of microbiotic soil crusts. Algolog. Stud., 109, 341362, 2003

Kvíderová, J.: Research on cryosestic communities in Svalbard: the snow algae of temporary snowfields in Petuniabukta, Central Svalbard. Czech Pol. Rep., 2, 8-19, 2012 
Biogeosciences Discuss., https://doi.org/10.5194/bg-2017-430

Manuscript under review for journal Biogeosciences

Discussion started: 16 November 2017

(c) Author(s) 2017. CC BY 4.0 License.

508 Laaka-Lindberg, S., Korpelainen, H., and Pohjamo, M.: Dispersal of asexual propagules in

509 bryophytes. J. Hattori Bot. Lab., 93, 319-330, 2003

511 Lalley, J. S., and Viles, H. A.: Recovery of lichen-dominated soil crusts in a hyperarid desert.

512 Biodivers. Conserv., 17, 1-20, 2008

Leavitt, S. D., and Lumbsch, H. T.: (2016) Ecological biogeography of lichen-forming fungi. in

Druzhinina, I. S., and Kubicek, C. P. (eds): Environmental and microbial relationships. Springer

Lee, H. N., Igarashi, Y., Chiba, M., Aoyama, M., Hirose, K., and Tanaka, T.: Global model simulation of the transport of Asian and Saharan dust: Total deposition of dust mass in Japan.

Lewis, J. M.: Ooishi's observation viewed in the context of jet stream discovery. Bull. Am.

Li, F., Ginoux, P., and Ramaswamy, V.: Distribution, transport, and deposition of mineral dust in the Southern Ocean and Antarctica: contribution of major sources. J. Geophys. Res., 113, D10207, 2008

Li, X.-R., Zhao, H.-Y., Wang, X.-P., Zhu, Y.-G., and O'Conner, P. J.: The effects of sand stabilization and revegetation on cryptogam species diversity and soil fertility in the Tengger Desert, Northern China, Plant Soil, 251, 237-245, 2003

Li, X. R., Xiao, H. L., He, M. Z., and Zhang, J. G.: Sand barriers of straw checkerboards for habitat restoration in extremely arid desert regions, Ecol. Eng., 28, 149-157, 2006 patterns of realized dispersal beyond the close vicinity of a sporulating moss. PloSONE, 7 , e31987, 2012

Macedo, M. F., Miller, A. Z., Dionísio, A., and Saiz-Jimenez, C.: Biodiversity of cyanobacteria and green algae on monuments in the Mediterranean Basin: an overview, Microbiol., 155, 34763490, 2009

Maestre, F.T., Martín, N., Díez, B., López-Poma, R., Santos, F., Luque, I., and Cortina, J.:

545 Watering, fertilization, and slurry inoculation promote recovery of biological crust function in 546 degraded soils. Microbial Ecol., 52, 365-377, 2006 
Biogeosciences Discuss., https://doi.org/10.5194/bg-2017-430

Manuscript under review for journal Biogeosciences

Discussion started: 16 November 2017

(c) Author(s) 2017. CC BY 4.0 License.

Marshall, W. A.: Aerial dispersal of lichen soredia in the maritime Antarctic. New Phytol., 134, 523-530, 1996

Marshall, W. A.: Seasonality in Antarctic airborne fungal spores. Appl. Environ. Microbiol., 63, 2240-2245, 1997

Marshall, W. A., and Chalmers, M. O.: Airborne dispersal of Antarctic terrestrial algae and cyanobacteria. Ecograph., 20, 585-594, 1997

McGorum BC, Pirie RS, Glendinning L, McLachlan G, Metcalf JS, Banack SA, Cox PA, and Codd

GA.: Grazing livestock are exposed to terrestrial cyanobacteria. Veterinary Research 46:16, 2015

McLeman, R. A., Dupre, J., Berrang Ford, L., Ford, J., Gajewski, K., and Marchildon, G.: What we learned from the Dust Bowl: lessons in science, policy, and adaptation. Popul. Environ., 35, 417440, 2014

Meier, F. C., and Lindbergh, C. A.: Collecting microorganisms from the Arctic atmosphere: with field notes and material. Sci. Mon., 40, 5-20, 1935

Metzger, S. M., Balme, M. R., Towner, M. C., Bos, B. J., Ringrose, T. J., and Patel, M. R.: In situ measurements of particle load and transport in dust devils, Icarus, 214, 766-772, 2011

Miller, N. G., and McDaniel, S. F.: Bryophyte dispersal inferred from colonization of an introduced substratum on Whiteface Mountain, New York, Am. J. Bot., 91(8), 1173-1182, 2004

Muñoz, J., Felicísimo, Á. M., Cabezas, F., Burgaz, A. R., and Martínez, I.: Wind as a long-distance dispersal vehicle in the Southern Hemisphere, Science, 304, 1144-1147, 2004

Nickling, W. G.: Eolian sediment transport during dust storms: Slims River Valley, Yukon

Park, C.-H., Li, X. R., Zhao, Y., Jia, R. L., and Hur, J.-S.: Rapid development of cyanobacterial crust

581 10.1371/journal.pone.0179903, 2017 cyanobacteria in the hyper-arid Atacama Desert, Chile, J. Phycol., 50, 698-710, 2014 
Biogeosciences Discuss., https://doi.org/10.5194/bg-2017-430

Manuscript under review for journal Biogeosciences

Discussion started: 16 November 2017

(c) Author(s) 2017. CC BY 4.0 License.

Piñeiro, R., Popp, M., Hassel, K., Listl, D., Westergaard, K. B., Flatberg, K. I., Stenøien, H. K., and Brochmann, C.: Circumarctic dispersal and long-distance colonization of South America: the moss genus Cinclidium, J. Biogeog. 39, 2041-2051, 2012

Pohjamo, M., Laaka-Lindberg, S., Ovaskainen, O., and Korpelainen, H.: Dispersal potential of spores and asexual propagules in the epixylic hepatic Anastrophyll helleriannum, Evol. Ecol., 20, 415-430, 2006

Prospero, J. M.: Long-range transport of mineral dust in the global atmosphere: Impact of African dust on the environment of the southeastern United States, Proc. Nat. Acad. Sci., 96, 3396-3403, 1999

Prospero, J. M., and Lamb, P. J.: African droughts and dust transport to the Caribbean: climate change implications, Science, 302, 1024-1027, 2003

Prospero, J. M., and Mayor-Bracero, O. L.: Understanding the transport and impact of African dust on the Caribbean Basin, Bull. Am. Meteorol. Soc., September, 1329-1337, 2013

Qiu, G. Y., Lee, I.-B., Shimizu, H., Gao, Y., and Ding, G.: Principles of sand dune fixation with straw checkerboard technology and its effect on the environment. J. Arid Environ., 56, 449-464, 2004

Rahav, E., Paytan, A., Chien, C.-T., Ovadia, G., Katz, T., and Herut, B.: The impact of atmospheric dry deposition associated microbes on southeastern Mediterranean Sea surface water following an intense dust storm. Front. Marine Sci., 3, doi:10.3389/fmars.2016.00127, 2016

Rajeev, L., Nunes da Rocha, U., Klitgord, N., Luning, E. G., Fortney, J., Axen, S. D., Shih, P. M., Bouskill, N. J., Bowen, B. P., Kerfeld, C. A., Garcia-Pichel, F., Brodie, E. L., Northen, T. R., and Mukhopadhyay, A.: Dynamic cyanobacterial response to hydration and dehydration in a desert biological soil crust. Int. Soc. Microb. Ecol. J., 7, 2178-2191, 2013

Rangarajan, C., and Eapen, C. D.: (2012) Estimates of interhemispheric transport of radioactive debris by the east African low level jet stream. Journal of Geophysical Research: Oceans (19782012) 86:12153-12154, 2012 
Biogeosciences Discuss., https://doi.org/10.5194/bg-2017-430

Manuscript under review for journal Biogeosciences

Discussion started: 16 November 2017

(c) Author(s) 2017. CC BY 4.0 License.

621 Read CF, Duncan DH, Vesk PA, Elith J (2011) Surprisingly fast recovery of biological soil crusts

622 following livestock removal in southern Australia, J. Veg. Sci., doi:10:1111/j.1654-

623 1103.2011.01296.x, 2011

624

Rosselli, R., Fiamma, M., Deligios, M., Pintus, G., Pellizzaro, G., Canu, A., Duce, P., Squartini, A., Muresu, R., and Cappuccinelli, P.: Microbial immigration across the Mediterranean via airborne dust, Sci. Rep., 5, 16306, 2015

Rousseau, D.-D., Antoine, P., Kunesch, S., Hatté, C., Rossignol, J., Packman, S., Lang, A.,

(Nebraska, USA), Earth Planet. Sci. Lett., 262, 159-174, 2007

Sahu, N., and Tangutur, A. D.: Airborne algae: overview of the current status and its

Samad, L. K., and Adhikary, S. P.: Diversity of micro-algae and cyanobacteria on building facades

Schlichting, H. E.: The importance of airborne algae and protozoa, J. Air Pollut. Contr. Assoc.,

Sethi, S. K., Samad, L. K., and Adhikary, S. P.: Cyanobacteria and micro-algae in biological crusts 2012

647 Sharma, N. K, Rai, A. K., and Singh, S.: Meteorological factors affecting the diversity of airborne 648 algae in an urban atmosphere, Ecography, 29, 766-772, 2006 
Biogeosciences Discuss., https://doi.org/10.5194/bg-2017-430

Manuscript under review for journal Biogeosciences

Discussion started: 16 November 2017

(c) Author(s) 2017. CC BY 4.0 License.

St. Clair, L. L., Johansen, J. R., and Webb, B. L.: Rapid stabilization of fire-disturbed sites using a

Takeuchi, N.: Seasonal and altitudinal variations in snow algal communities on an Alaskan

Tesson, S. V., Skjøth, C. A., Šanti-Temkiv, T., and Löndahl, J.: Airborne microalgae: Insights, opportunities, and challenges, Appl. Environ. Microbiol., 82, 1978-1991, 2016

Tomaselli, L., Lamenti, G., Bosco, M., and Tiano, P.: Biodiversity of photosynthetic micro-

Uno, I., Eguchi, K., Yumimoto, K., Takemura, T., Shimizu, A., Uematsu, M., Liu, Z., Wang, Z., Hara, community structures in cryoconite holes upon high-Arctic glaciers, Svalbard, Biogeosciences,

Warren, S. D.: Ecological role of microphytic soil crusts in arid environments, in: Allsopp, D., 
Biogeosciences Discuss., https://doi.org/10.5194/bg-2017-430

Manuscript under review for journal Biogeosciences

Discussion started: 16 November 2017

(c) Author(s) 2017. CC BY 4.0 License.

686 Warren, S. D.: Role of biological soil crusts in desert hydrology and geomorphology: Implications

687 for military training operations, Rev. Eng. Geol., 22, 177-186, 2014

688

Warren, S. D., and Eldridge, D. J.: Biological soil crusts and livestock in arid ecosystems: Are they compatible? in: Belnap, J., and Lange, O. L. (eds), Biological soil crusts: structure, function and management, Springer-Verlag, Berlin, Germany, 401-415, 2001

692

Webb, R. H., Steiger, J. W., and Newman, E. B.: The response of vegetation to disturbance in Death Valley National Monument, California. US Geol. Surv. Bull., 1793, 1988

Weber, B., Büdel, B., and Belnap, J. (eds): Biological soil crusts: an organizing principal in drylands, Springer International Publishing, Cham, Switzerland, 2016

698

Wilshire, H. G.: The impact of vehicles on desert stabilizers, In: Webb, R. H., and Wilshire, H. G. (eds), Environmental effects of off-road vehicles, Springer-Verlag, New York, 31-50, 1983

701

Womack, A. M., Bohannan, B. J. M., and Green, J. L.: Biodiversity and biogeography of the

Xu, S., Yin, C., He, M., and Wang, Y.: A technology for rapid reconstruction of moss-dominated soil crusts. Env. Eng. Sci., 25, 1129-1137, 2008

Zhang, J., Zhang, C., Ma, X., Zhou, N., Wang, H., and Rissler, P. S.: Dust fall and biological soil crust distribution as indicators of the aeolian environment in China's Shapatou railway protective system, Caten,a, 114, 107-118, 2014 
Biogeosciences Discuss., https://doi.org/10.5194/bg-2017-430

Manuscript under review for journal Biogeosciences

Discussion started: 16 November 2017

(c) Author(s) 2017. CC BY 4.0 License.

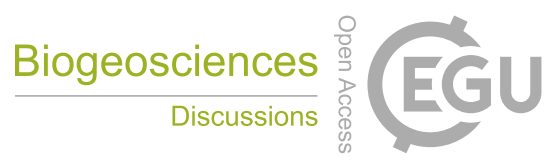

(c) (1)

718 organizing principle in drylands, Springer International Publishing, Cham, Switzerland, 499-523,

7192016 